\title{
THE MARBLE LION FROM LION TUMULUS NEAR KERCH TO THE QUESTION ABOUT SCULPTURES ON THE CIMMERIAN BOSPORUS
}

\begin{abstract}
In this article the author presents a very rare find from the 1894 excavations of the so-called Lion Tumulus near Kerch. It is a huge marble statue of a lion, which is shown leaning on the head of a bull supported by its left paw. The Lion Tumulus is dated by an inscription to AD 14/15 and can be classified as a Royal tomb. Perhaps a rival of the Bosporan King Aspurgus in the struggle for the throne was buried there.
\end{abstract}

Keywords: Bosporan Kingdom, Lion Tumulus, sculpture

\author{
MARMUROWY LEW Z LWIEGO KURHANU KOŁO KERCZU. \\ PRZYCZYNEK DO KWESTII RZEŹBY NA BOSPORZE KIMMERYJSKIM
}

\begin{abstract}
ABSTRAKT W prezentowanym studium autor analizuje znalezisko, dokonane w 1894 r. w trakcie wykopalisk na Lwim Kurhanie koło Kerczu. Odkryto tam marmurową rzeźbę lwa, opierającego łapę na głowie byka. Grobowiec, datowany jest, na podstawie znalezionej inskrypcji, na 14/15 r. n.e. Uznano go za grobowiec królewski. Możliwe, że pochowano w nim rywala króla Bosporu Aspurgosa.
\end{abstract}

Słowa kluczowe: Królestwo Bosporańskie, Lwi Kurhan, rzeźba

An additional aspect for the study of cultural relations between the Bosporus and Rhodes are the finds of the work of Rhodian sculptors there. ${ }^{1}$ Until recently this consisted of a small statue of Aphrodite, the so-called Aphrodite of Taman. It found at Kepoi on the Taman peninsula more than 50 years ago and dates from the second half of the 2 nd century BC, ${ }^{2}$ when connections between the Bosporan cities and Rhodes can be noted. Many researchers have noted, this statue has an almost complete analogy in the sculpture (Fig. 1) found in 1927, at present at the Archaeological Museum of Rhodes. ${ }^{3}$ In size, the Rhodian sculpture is somewhat larger then Aphrodite of Taman, but the type and marble processing technique is very close to the statue from Rhodes. The two statues differ from

1 The study was conducted for the state work № 0184-2019-0005. "Culture of Classical States of the Northern Black Sea Region. Subcultures of the ruling elite and ordinary population".

2 Sokol'skiy1964, 111, 114-115, rys. 10; Savostina 2012, 183, rys. 144.

3 Jacopi 1931, 16-22, pl. 2, fig. 9-12. one another only in small details: the statue from Rhodes is turned to the viewer's left side, and the right, not the left, leg is supported by a pedestal. Also there are other finds which can be attributed to Rhodian or Koan workshops.

A good example is a huge marble statue of a lion, which was found during illegal excavations on 10th of September 1894 near Kerch, in the tumulus on the estate of Colonel Andrei Voloshkevich. ${ }^{4}$ The Director of the Kerch Museum Karl Dumberg (1862-1931) immediately understood the value of this accidental find, because in Kerch a well-preserved marble statue had not been found for a long time. The statue was found in a pit beneath the eastern part of the tumulus (Fig. 2). It had a length of $2.22 \mathrm{~m}$, a height of $1.61 \mathrm{~m}$, and a width of $0.64 \mathrm{~m}$. The net weight of the sculpture was about 2.5 tons (Fig. 3). Later the lion statue became the jewel of the Hermitage's Department of the Classical world and repeatedly attracted the attention of researchers. ${ }^{5}$

4 Goroncharovskiy 2017, 111-129.

5 Sokolov 1973, 131, No. 138; Sokolov 1999, 363364; Savostina 2012, 285, fig. 237. 


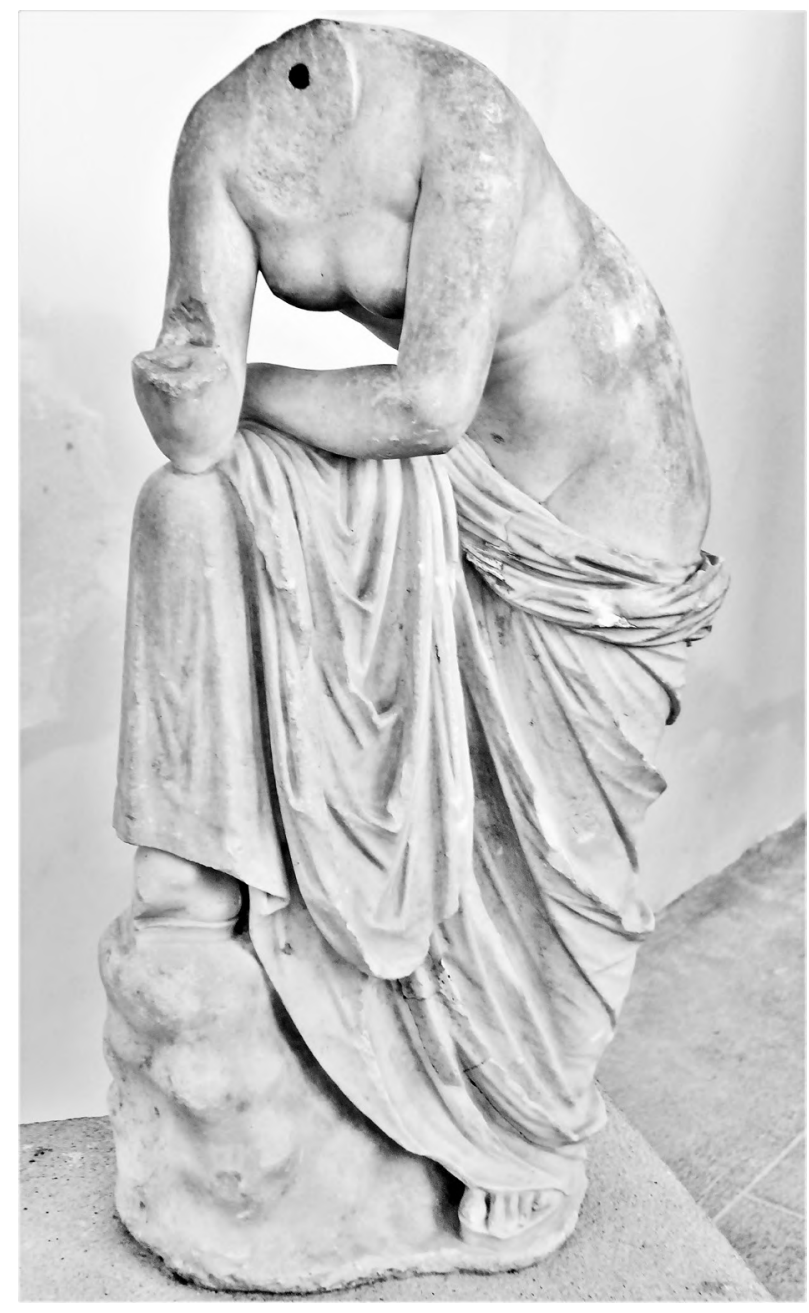

Fig. 1. Statue of Aphrodite from Archaeological Museum of Rhodes (Jacopi 1931, pl. 2, fig. 9)

Behind the lion a massive slab of sandstone was placed. It had several of the so-called Sarmatian tamga-signs inscribed on the edge. Nearby some fragments of architectural details of the Doric order were found. It is possible that these fragments came from a high pedestal on which the sculpture of the lion was placed. In support of this a interpretation, a fragment of a wooden sarcophagus found at Kerch in 1872 preserves a representation on a lion in combination with such architectural element (Fig. 4). ${ }^{6}$

The Chairman of the Imperial Archaeological Commission count Alexei Bobrinskiy was ordered to buy the sculpture, send it to the Hermitage Museum and then investigate the area where the lion was uncovered. Further excavations of the burial complex, which received the name Lion Tumulus, provided the evidence for dating it. The excavations lasted two field seasons. During this time the tumulus with a height more than $6 \mathrm{~m}$ was

6 Rostovtsev 1913, 215, rys. 44. completely removed. By the standards of archaeological research for that time in Kerch it was rare case when a tumulus was excavated entirely under careful supervision over the course of works.

Just two steps away from the Northern edge of the pit which contained the marble lion, workers came across a huge slab of fine sandstone with carefully carved large tamga-signs. They were similar to the signs used by the Bosporan kings during the first centuries AD. Then the parallel stone walls of the dromos measuring $13 \mathrm{~m}$ long, and a small central tomb were cleared. The total area of the central tomb was only $7 \mathrm{~m}^{2}$. Its eastern part was almost completely destroyed. In the western part, an oblong hollow was revealed, containing the remains of a sarcophagus carved out of a single block of sandstone. Initially it was paved with floor slabs. However this did not save the burial from looting. The surface of the sarcophagus was worked only on the upper faces, and it therefore it was originally going to be placed under the floor. The sarcophagus lid, according to its one surviving fragment, was of gable shape with acroteriae at the corners.

In addition re-deposited more earlier material of the 4th century BC, fragments of glass vessels, and the remains of a golden funeral wreath composed of thin gold clover leaves of the 1st century $\mathrm{BC}$ were found. ${ }^{7}$ A broken slab, which found on the floor of the tomb, deserves particular attention. On the front side it had an inscription (Fig. 5): 'Alkimos, son of Askla, and his wife Philopatra, daughter of Alkiy, built this monument in the year $311, .8$ The year corresponds to $14 / 15$ AD. Accordingly Karl Dumberg this tomb is dated approximately to the 1 st century $\mathrm{BC}$ or soon after the turn of our era. Most likely, the inscription gives us the names of people that erected the funeral monument topped with a huge sculpture of a lion.

The figure of lion trampling the head of bull is connected, most probably, with conceptions related to the mythology of Mithraism. In this case the general symbolic meaning is obvious: the bull is a sacrifice in the name of the revival of new life. The blood spilled gives a chance to be reborn, to find immortality. ${ }^{9}$ In the ancient world, such figures often served as a kind of guardian of the grave and a symbol of supreme power and greatness. For example, one recalls such an animal in marble sat on a pedestal at the site of the battle of Chaeronea in $338 \mathrm{BC}$.

\footnotetext{
7 Treyster 2015, 84 .

CIRB 335.

9 Ivanov 2017: 174.
} 


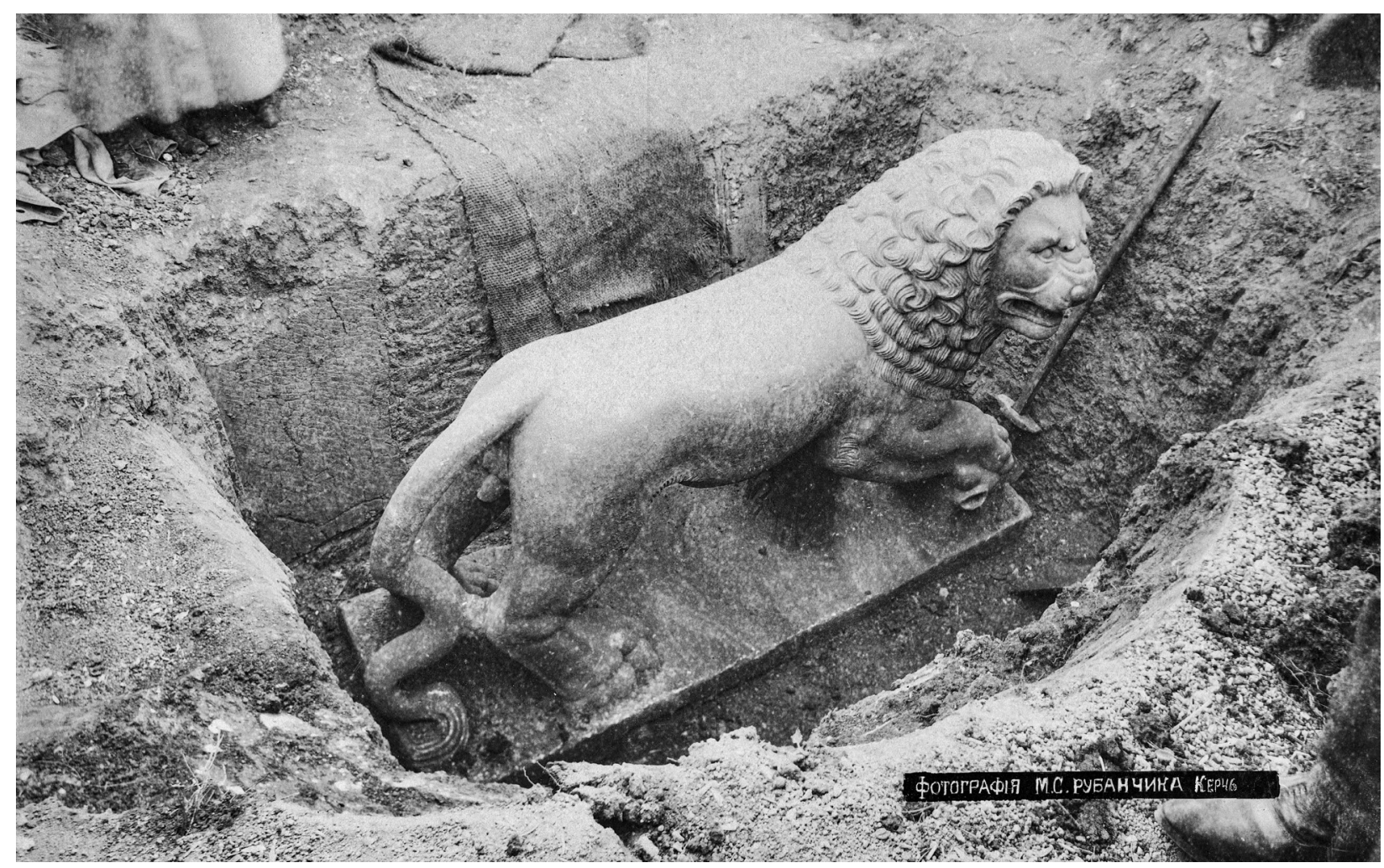

Fig. 2. Lion Tumulus. Statue of lion in the discovery moment (Photograph from Scientific Archive of the Institute for the History of Material Culture, St.-Petersburg: fund 1, 1894, case 158, page 150)

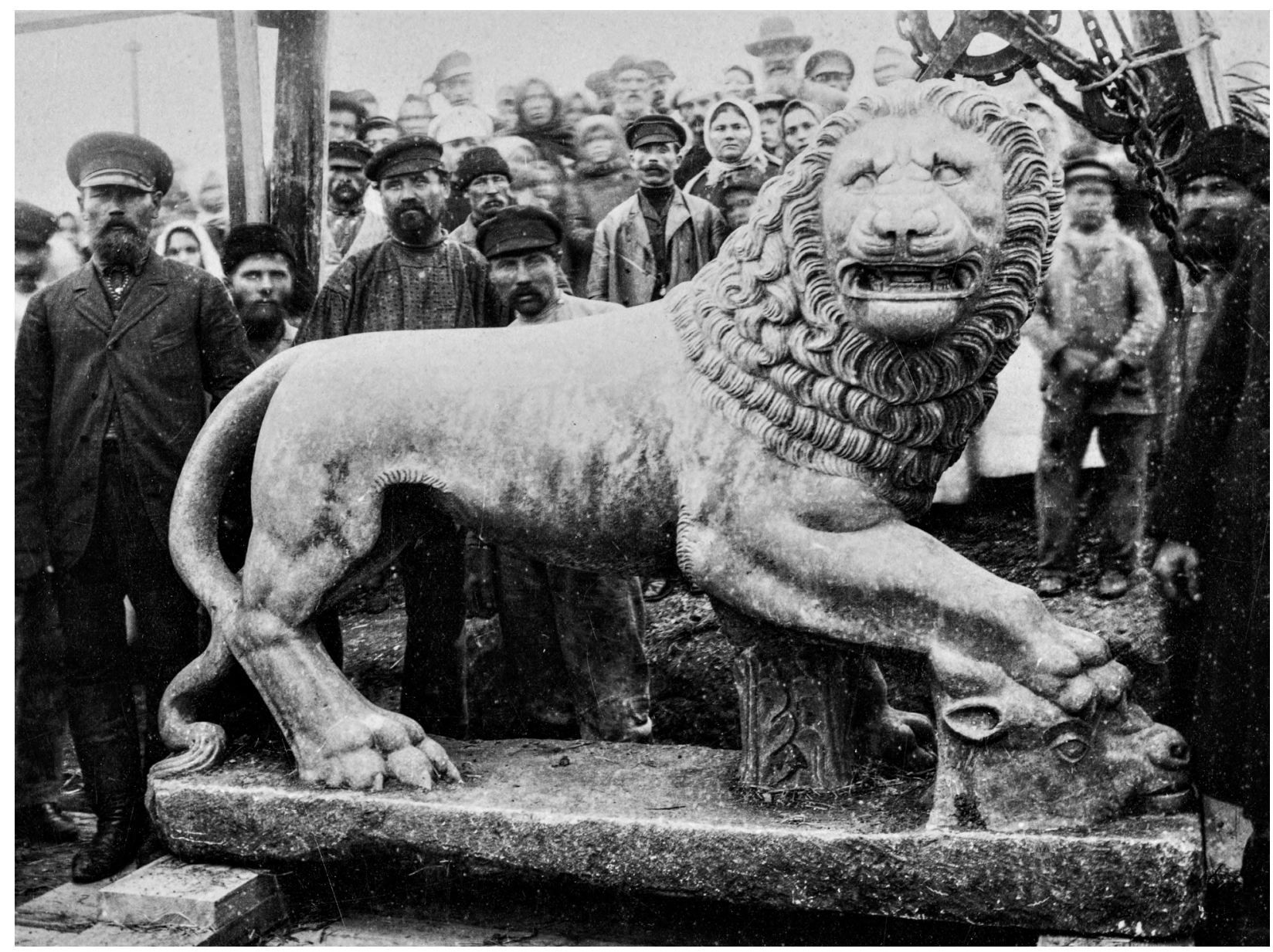

Fig. 3. Lion statue after lifting out of the pit (Photograph from Scientific Archive of the Institute for the History of Material Culture, St.-Petersburg: fund 1, 1894, case 158, page 152) 


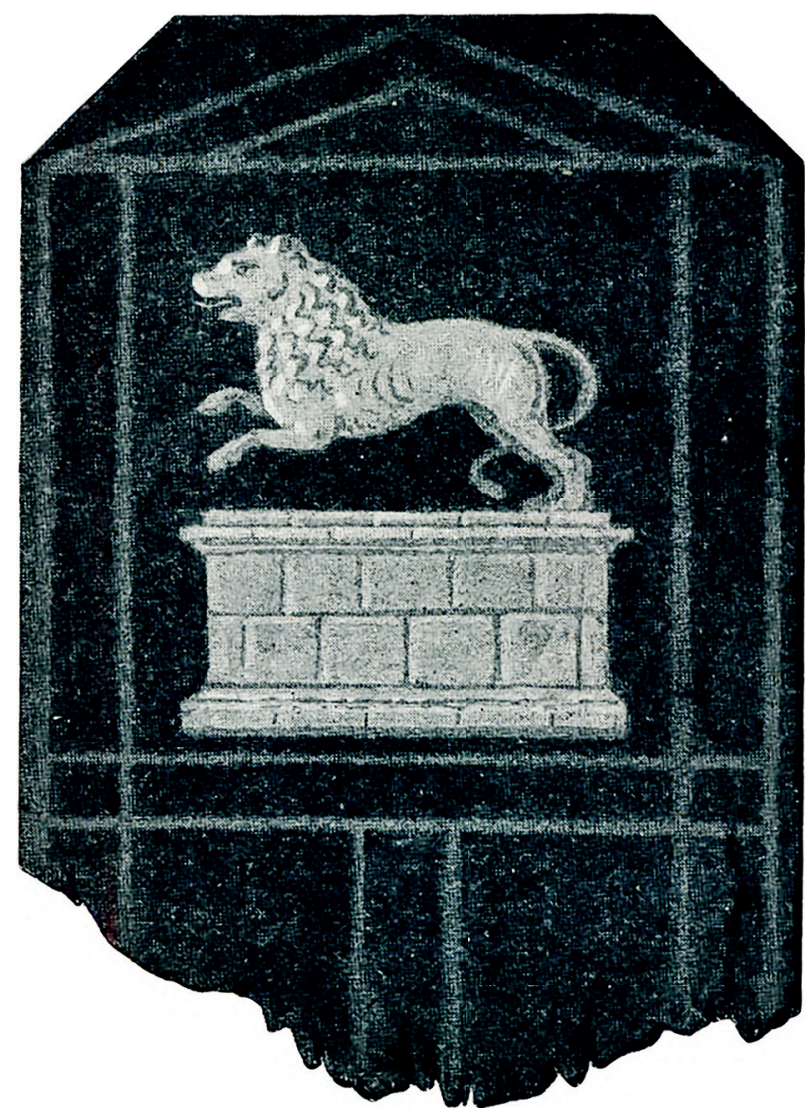

Fig. 4. Fragment of wooden sarcophagus found at Kerch in 1872 (by Rostovtsev 1913, 215, rys. 44)

In his report Karl Dumberg specifically noted the fact that the sarcophagus, the inscribed slab and the slabs with tamga-signs were made of the same material, a type of sandstone which is not to be found on the Kerch Peninsula. Its nearest deposits are found about $200 \mathrm{~km}$ to the west. It is interesting to note that similar signs to the tamga-signs found in the tumulus, are also to be found to the west of the boundaries of Bosporus: in Scythian Neapolis, Chersonesus and Olbia. ${ }^{10}$ How is this to be explained? If we take the traditional date of construction of the Lion Tumulus, it is possible that it is associated with political events that took place at this time on the Bosporus. The termination of the emission of local gold staters between $10 / 11$ and $13 / 14 \mathrm{AD}$, obviously testifies to a struggle for power in these years, and the short-term occupation of the Bosporan throne by a the ruler not recognized by Rome. ${ }^{11}$ Apparently this ruler, who was buried in the Lion Tumulus, was associated with the late Scythians and Sarmatian clans of the Crimean steppes, and made a successful attempt to take power. We know that the Bosporan king Aspurgus went to Rome shortly before the death of Emperor Augustus in 14 AD. Apparently his purpose was to achieve confirmation of his rights to the throne, together with financial and military assistance. This mission was successful no later than the middle of $15 \mathrm{AD}$.

We know nothing about the fate of Aspurgus's opponent, but we can assume that he died not long after. In this respect the Lion Tumulus may well lay claim to be his place of burial. The assumption of the high status of the burial in the tumulus is supported by lion statue which traditionally served as a symbol of Supreme power and greatness, and the presence of the large tamga-signs, already mentioned above, which come from the category of "Royal" signs, on the slab next to the lion.

Perhaps after the return of Aspurgus to the Bosporus, and the suppression of all rebel statements, the fate of tomb of the preceding Bosporan ruler was decided in accordance with the Roman practice of damnatio memoriae. This was a special form of posthumous punishment applied to state criminals: usurpers of power, participants in conspiracies and emperors turned evil. In such cases any material evidence of the existence of such a person: statues, tombstones, together with all references in written documents, were to be destroyed in order to erase the memory of the deceased. It is possible that 'a lot of small fragments of beautiful white marble', ${ }^{12}$ mentioned in Karl Dumberg's excavation report, come from the erasure of the inscription on pedestal bearing the name of the person buried in the tomb below.

The dating of the sculpture from Lion Tumulus to Roman times is evidenced by the predominance of decorative and conventional interpretations of the image of the lion, which is typical for this period. Exact analogies for them cannot be found.

\section{Abbreviations}

CIRB (KBN) - Struve V. V. (ed.) Corpus Inscriptionum Regni Bosporani (Korpus bosporskih nadpisej), MoskvaLeningrad 1965
10 Yatsenko 2001, 141, rys. 6.

11 Choref 2013, 148.
12 Scientific Archive of the Institute for the History of Material Culture: fund 1, 1894, case 158, page 35. 


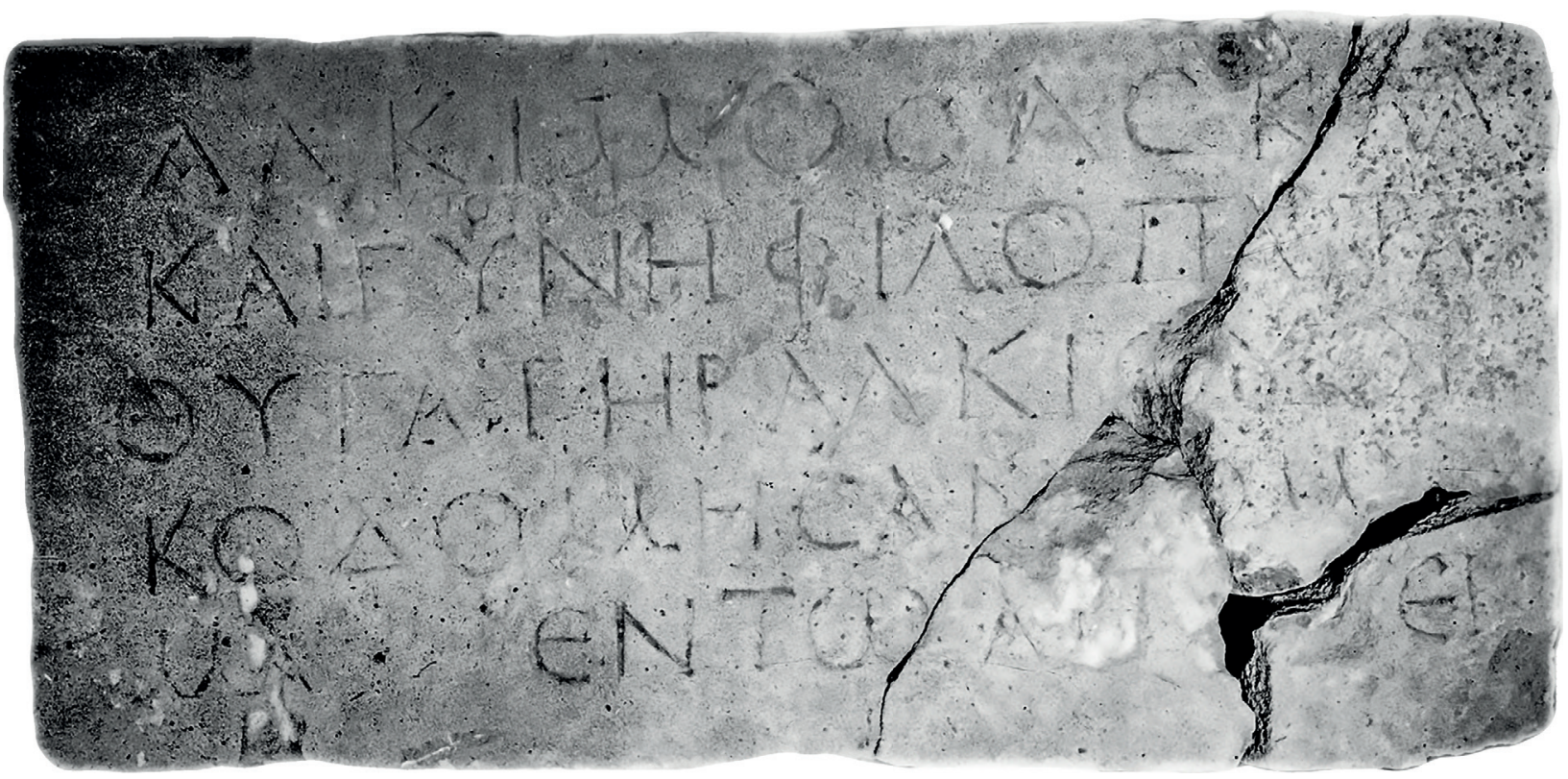

Fig. 5. Inscription of Alkimos and Philopatra (Photograph from Scientific Archive of the Institute for the History of Material Culture, St.-Petersburg: fund R I, case 344, page 3)

Literature

Choref M. M. 2013. Dinasticheskaya istoriya Bospora na rubezhe n. e. po dannym numizmatiki. "Stratum plus" 6, 127-158.

Goroncharovskiy V. A. 2017. Delo o L'vinom kurgane. In: L. Vishnyatskiy (ed.), Neizvestnye stranitsy arkheologii Kryma: ot neandertal 'tsev do genueztsev. Sankt-Petersburg.

Ivanov P. V. 2017. Sakral'nye zhivotnye $i$ rasteniya $v$ miphologii rimskogo mitraizma. In: N. I. Vinokurov (ed.), Drevniy mir: Istoriya $i$ arkheologiya. Moskva, 173-181.

Jacopi G. 1931. Monumenti di scultura del Museo Archeologico di Rodi, 2. Bergamo.

Rostovtsev M. I. 1913. Antichnaya dekorativnaya zhivopis'na juge Rossii. Sankt-Petersburg.
Savostina E. A. 2012. Ellada i Bospor. Greheskaja skul'ptura na Severnom Ponte. Simferpol-Kerch.

Sokolov G. I. 1973. Antichnoe Prichernomor'e. Leningrad.

Sokolov G. I. 1999. Iskusstvo Bosporskogo tsarstva. Moskva.

Sokol'skiy N. I. 1964. Svyatilishche Aphrodity v Kepakh. "Sovetskaya Arkheologia" 4, 101-118.

Treyster M. Ju. 2015. Zoloto Fanagorii. Tipologicheskiy, stilisticheskiy $i$ khronologicheskiy analiz. In: V. D. Kuznetsov (ed.), Fanagoria. Rezul'taty arkheologicheskikh issledovaniy. Moskva, 77-181.

Yatsenko S. A. 2001. Znaki-tamgi iranoyazychnykh narodov drevnosti i rannego srednevekov'ya. Moskva.

Vladimir Goroncharovskiy ORCID 0000-0002-4405-716X Institute for History of Material Culture RAS goronvladimir@yandex.ru 